\title{
Discriminating Decentralization
}

\author{
FEDERALISM AND THE HANDLING OF ASYLUM \\ APPLICATIONS IN SWITZERLAND, 1988-1996
}

\author{
THOMAS HOLZER \\ Institute of Political Science \\ University of Bern \\ GERALD SCHNEIDER \\ Department of Politics and Management \\ University Konstanz
}

THOMAS WIDMER

Institute of Political Science

University of Zürich

Federalism belongs to those institutions that usually attract more admirers than critics. This study investigates whether decentralized decision making in the asylum domain undermines the principle of equality in the handling of individual cases. The externalities that power delegation creates are examined, and a princi$\mathrm{pal} / \mathrm{agent}$ framework is developed to show how state discretion in the implementation of a unifying federal measure arises. The model distinguishes between positive and negative discrimination in the acceptance of asylum applications. The empirical analysis of approximately 180,000 cases demonstrates that the probability of negative discrimination is partly a function of the organizational principles that characterize the asylum policies of the 26 Swiss states (cantons).

$\mathbf{O}$ ne of the persistent criticisms of Western European asylum policy making aims at the considerable differences in the acceptance of applications from refugees with a

AUTHORS' NOTE: Earlier versions of this article have been presented at the annual meeting of the Rational Choice Section of the German Political Science Association, February 27-28, 1998, Schloß Rauischholzhausen, Gießen, Germany, and at meetings at the University of Konstanz and the University of Bern. We would like to thank Thomas Plümper, Thomas König, Godehart Wakenhut, Andreas Wimmer, Rainer Schnell, and Simon Hug for their helpful comments. Financial support by the Swiss National Science Foundation (Special Program in Migration Studies, grant no. 4039-044836/1), the Foundation Bevölkerung, Migration, Umwelt, the Berner Hochschulförderung, and the cooperation program between the University of Konstanz and the Kanton Thurgau is gratefully acknowledged. None of these institutions is in any way responsible for our interpretations. The data set used in this article was obtained with special permission from the Swiss Federal Office for Refugees. Every entry in this data set was made completely anonymous before the statistical analysis. However, because it is theoretically still possible to reconstruct the identity of some asylum seekers in very small cantons, the data examined in this article cannot be used without the written permission of the Swiss Federal Office for Refugees and the authors. 
similar background. This divergence contradicts the universalistic impetus that characterizes the international refugee regime to which all Organization of Economic Cooperation and Development (OECD) member states formally adhere. The continuous violation of the Geneva Convention became especially pertinent in the attitude toward refugees from Bosnia and Kosovo. Whereas some states kept their doors largely closed, Austria, Germany, Sweden, and Switzerland were relatively open toward asylum seekers from the war-torn parts of ex-Yugoslavia. But the liberal attitude immediately started to wane in some of the more tolerant states when the peace process in the two regions seemingly stabilized. Especially Switzerland and Germany started to send back thousands of refugees into their areas of origin and thus into a future that was more than uncertain. The unequal treatment that these asylum applicants had to endure highlights the discriminatory potential that exists in Western Europe despite the substantial and largely underestimated harmonization of the asylum policies (Holzer and Schneider 1999; Keely and Stanton Russel 1994).

In this article, we want to investigate the capacity for unequal treatment that exists in a political entity that has moved further in its cooperation in the asylum domain but still maintains a partially decentralized handling of the unified asylum procedure. Our analysis suggests that such differences will most likely persist even if the European Union (EU) moves further toward a uniform procedure and establishes an effective burden-sharing mechanism (Vanheule 1997). We principally perceive such discrimination as an almost logical function of the control problems that power delegation to lower tier governments creates. In line with the formal literature on agency discretion, we start from the assumption that preferences of central decision makers and their agents in subterritorial units might not necessarily coincide. The ensuing discrepancy creates diverging standards and helps the interests of those regional forces whose preferences deviate from the one of the central government. The discriminatory potential of the decentralized decision making is an old topic in the literature on federalism (e.g., Riker 1964). The equity problems are especially pertinent in the asylum domain. In the United States, for instance, an evaluation study claimed that the number of days refugees remain in detention is significantly higher in New York than anywhere else (New York Times, June 22, 1998).

Our theoretical and statistical analysis refers to the similarly federal Switzerland in which the cantons as the main subterritorial units possess substantial discretionary power in asylum procedures. Albeit bound to the same national law, the 26 Swiss cantons can, in principle, treat asylum requests from similar individuals differently. This leeway derives from the way in which the central authorities typically delegate the implementation of certain rules to the subterritorial units. The ensuing task division yields the cantons considerable informal influence on asylum decisions, opening the door for both positive and negative discrimination.

Based on a data set of more than 180,000 asylum applications to Switzerland from 1988 to 1996, we analyze whether requests from individuals with an identical background face the same chances of recognition. ${ }^{1}$ The statistical tests particularly consider salient organizational features, the size of the cantons, the linguistic affiliation, the res- 
idents' attitude toward asylum seekers, and the proportion that foreigners constitute in the territorial subunit. We control for the most important individual attributes of asylum seekers and show that the likelihood of a positive decision is more than twice as high in some states than in others. In general, cantons with a centralized asylum administration are associated with lower recognition rates. The same holds true for states with a high proportion of foreigners and negative attitudes in the population toward asylum seekers. If we combine these two factors, the results are less clear-cut. Whereas cantons with both a high share of foreigners and strong negative feelings in the population toward asylum seekers tend to discriminate negatively, the opposite is true for states with a low proportion of foreigners. Whereas both small and large states handle asylum requests in a more tolerant fashion, middle-sized cantons act more restrictively.

The article is structured as follows. We first present some comparative evidence of the discriminatory potential that is linked to decentralized forms of asylum policy implementation. Next, we discuss the relationship between federalism and the principle of equality from a theoretical point of view. The hypotheses that we derive from this analytical framework are tested statistically in the form of logit regressions. The article concludes with some remarks on the implications that our research could have for the discussion on the interrelationship between international politics and federalism.

\section{THE DISCRIMINATORY POTENTIAL OF ASYLUM LAW IMPLEMENTATION}

Despite the growing importance of the EU, asylum policy making in Western Europe is still based on a mixture of unilateral, bilateral, and multilateral arrangements. Most nation-states have, for instance, introduced severe restrictions in their asylum laws to deter refugees from applying for asylum. ${ }^{2}$ These legal measures are accompanied by international agreements that try to prevent a race toward more and more restrictive standards. As a consequence, asylum policy making in the EU between the early 1980s and the mid-1990s has been characterized by a relatively harmonious convergence toward a "Fortress Europe" (Holzer and Schneider 1999). The antiliberal tendencies also became apparent in the large number of bilateral agreements that Western European states concluded with Eastern and Central European countries. These treaties force the signatory states to take back those refugees who have stayed there for a while before applying for asylum in the "partner" state. ${ }^{3}$

2. In Switzerland, such efforts bore a considerable impact on the number of applications in subsequent years (Holzer, Schneider, and Widmer forthcoming). Joppke (1997) illustrates for the United States, Germany, and Great Britain that the nation-state still has the capacity to control immigration.

3. According to Achermann (1997), OECD states cooperate in more than 70 agreements. Until the introduction of the Amsterdam Treaty, the most significant multilateral agreements in Western Europe were the Dublin convention and the Schengen agreement. The resolution on minimum guarantees for asylum procedures, which the Justice and Home Affairs Council of the European Union adopted on June 20 and 21 , 1995, aims at the introduction of common standards for the asylum procedure. See Hailbronner and Thiery (1997) for a legal analysis of Schengen and Dublin, and Boeles and Terlouw (1997) for a discussion of the resolution. Hailbronner (1998) analyzes the legal implications of the Amsterdam Treaty in this policy area. 
TABLE 1

Yearly Recognition Rates for Selected Western European Countries, 1985-1995

\begin{tabular}{|c|c|c|c|c|c|c|c|}
\hline Year & Austria & Belgium & France & Germany & Italy & Switzerland & $\begin{array}{c}\text { United } \\
\text { Kingdom }\end{array}$ \\
\hline 1985 & 45 & n.a. & 43 & 40 & 7 & 14 & 22 \\
\hline 1986 & 36 & n.a. & 39 & 22 & 4 & 12 & 12 \\
\hline 1987 & 31 & n.a. & 33 & 12 & 7 & 9 & 13 \\
\hline 1988 & 27 & 38 & 35 & 11 & 4 & 7 & 25 \\
\hline 1989 & 19 & 49 & 28 & 6 & 56 & 5 & 33 \\
\hline 1990 & 7 & 37 & 15 & 5 & 60 & 5 & 26 \\
\hline 1991 & 13 & 26 & 20 & 8 & 5 & 3 & 9 \\
\hline 1992 & 10 & 28 & 28 & 5 & 5 & 5 & 3 \\
\hline 1993 & 8 & 29 & 28 & 5 & 9 & 15 & 8 \\
\hline 1994 & 8 & 31 & 24 & 10 & 18 & 13 & 5 \\
\hline 1995 & 13 & 32 & 16 & 17 & 17 & 15 & 6 \\
\hline
\end{tabular}

SOURCE: International Geneva Convention, UNHCR.

NOTE: Recognition rates are defined as the percentage of positive decisions relative to all decisions made in a given year.

Because these measures partly contradict each other, asylum policy making in an imperfectly integrated political entity like Western Europe leads almost inevitably to considerable differences in the ways in which individual cases are handled. Table 1 shows how the recognition rates for asylum seekers have developed in a selected number of countries. The recognition rate stands for the chances that the state authorities recognize an individual asylum seeker as a refugee. The figures reported in Table 1 make it evident that this crucial indicator varies considerably both across countries and across time. Although Italy accounted for the lowest recognition rate in 1985, it accepted the largest relative number of asylum seekers only 4 years later. The recognition rates of Switzerland and the United Kingdom, conversely, were more or less consistently below the average.

Table 1 demonstrates that the fate of an asylum seeker can depend largely on when and where the asylum claim is made. Yet, these aggregated numbers are too rough a measure to adequately assess the individual chance of admission, and they offer no guarantee that a particular application faces a higher likelihood of recognition in one country than in another. A first step toward the development of a more realistic proxy for the probability of a positive decision is to control for the country of origin. Unfortunately, reliable statistics on country specific recognition rates are often not available. We therefore present only the temporary development of the recognition rates for Sri Lankan and Turkish asylum seekers in Germany and Switzerland, respectively.

As Table 2 shows, refugees from Sri Lanka had only a modest chance to be admitted to Switzerland during the decade from 1986 to 1995. Moreover, the development of the recognition rate is characterized by a downward trend, reaching a minimum of $0.6 \%$ in 1995. In this year, the Swiss Federal Office for Refugees (FOR) decided only 26 out of 4,557 cases in favor of the applicants. The German recognition rate, by con- 
TABLE 2

Recognition Rates for Sri Lankan and Turkish Asylum Seekers in Germany and Switzerland, 1986-1995

\begin{tabular}{|c|c|c|c|c|}
\hline \multirow[b]{2}{*}{ Year } & \multicolumn{2}{|c|}{ Germany } & \multicolumn{2}{|c|}{ Switzerland } \\
\hline & Sri Lanka & Turkey & Sri Lanka & Turkey \\
\hline 1986 & 20.6 & 4.5 & 6.8 & 6.9 \\
\hline 1987 & 15.6 & 8.8 & 3.4 & 6.5 \\
\hline 1988 & 0.9 & 7.3 & 3.7 & 4.3 \\
\hline 1989 & 0.1 & 4.3 & 4.5 & 3.0 \\
\hline 1990 & 0.5 & 4.8 & 5.8 & 3.4 \\
\hline 1991 & 3.2 & 8.3 & 3.5 & 5.8 \\
\hline 1992 & 24.8 & 9.7 & 1.8 & 10.7 \\
\hline 1993 & 33.9 & 14.3 & 2.1 & 22.8 \\
\hline 1994 & 23.6 & 20.9 & 1.0 & 43.9 \\
\hline 1995 & 14.6 & 21.4 & 0.6 & 47.1 \\
\hline Average & 16.4 & 12.9 & 1.9 & 9.1 \\
\hline
\end{tabular}

SOURCE: Personal communications with the Bundesamt für die Anerkennung ausländischer Flüchtlinge, Nürnberg (Federal Office for the Recognition of Foreign Refugees, Nürnberg, Germany) and the Bundesamt für Flüchtlinge, Bern (Federal Office for Refugees, Bern, Switzerland).

NOTE: Recognition rates are defined as the percentage of positive decisions relative to all decisions.

trast, varied much more. In the period between 1988 and 1990, the recognition rate dropped to extremely low values; the German Federal Office for the Recognition of Foreign Refugees approved no more than 4 out of 3,892 applications in 1989, for instance. But except for this short period when the doors were basically closed, German authorities were in general much more favorable toward Sri Lankan asylum seekers than their Swiss counterparts. Whereas Germany admitted 10,373 refugees from Sri Lanka between 1986 and 1995 (recognition rate of 16.4\% on average), Switzerland decided only 352 applications positively (recognition rate of $1.9 \%$ on average). ${ }^{4}$

Much less variation characterizes the ways in which the two receiving states treat Turkish asylum seekers. In both countries, the recognition rate has considerably increased in recent years: almost every second asylum seeker from Turkey was admitted to Switzerland in 1995. Nevertheless, Germany is, on average, more generous than Switzerland, granting asylum to a total of 27,141 Turkish refugees between 1986 and 1995. This corresponds to a recognition rate of $12.9 \%$ on average. In Switzerland, the respective number amounted to 4,701 or $9.1 \%$ on average.

4. It should be noted that not every rejected asylum seeker is immediately sent back. The principle of nonrefoulement, which states that no refugee shall be returned if his or her life or freedom is threatened, obliges a host country to provisionally admit such persons. However, they will practically be repatriated as soon as the situation makes it possible. If such a repulsion is not immediately feasible, some of these refugees typically continue to stay in their host country for a considerable time. In Switzerland, this was especially the case for Sri Lankan asylum seekers who were allowed to stay under some newly created immigration category but not as recognized refugees. For an ethnological study of asylum seekers from Sri Lanka in Switzerland, see McDowell (1996). 
The considerable differences in the recognition rates between Germany and Switzerland strongly suggest that asylum seekers with a similar background do not face the same chance of recognition. A rational asylum seeker (or rather the rational organization that coordinates the flight) will consequently consider past recognition rates when she decides where to apply for asylum. However, opting for Switzerland to file the claim does not guarantee that the chances for a positive decision correspond with the general recognition rate in this country. The uncertainty stems from the federal division of power that yields the 26 federal units considerable responsibility in the handling of the asylum procedure. In the decentralized political system of Switzerland, state authorities prepare the decision, which is formally made by the FOR. Although the Swiss cantons thus do not legally grant asylum, it is in their hands to influence the decision in the direction they prefer.

Table 3 offers a first impression of the discriminatory potential that the federalist delegation of power creates. Most obviously, recognition rates by cantons vary from approximately $5 \%$ to more than $12 \%$. The central authorities distribute asylum seekers to the cantons according to a formula that is based on the relative size of a state. Because these decisions do not depend explicitly on a claimant's place of origin, we can assume that the composition of the asylum seekers' population in the cantons probably does not differ much. This arbitrary composition implies that significant variations in the recognition rates across cantons have to be attributed to discrimination based on unequal administrative behavior. ${ }^{5}$

In the eyes of a possible asylum seeker, another key variable in the comparative evaluation of asylum policies is the time that passes until the individual case is decided. ${ }^{6}$ Although the refugees probably favor a quick positive decision, they might start striving for longer durations if the recognition rate decreases to a point at which the chance of recognition becomes truly marginal. Unfortunately, we do not possess data on average durations of asylum procedures for countries other than Switzerland. Table 3 demonstrates that not only the average recognition rate but also the average duration varies considerably across Swiss cantons. Whereas cases in the responsibility of Zürich, the largest canton, were decided by the central authority after 488 days on average, tiny Appenzell Innerrhoden, with a population of some 14,000 people, used only 237 days. It goes without saying that intra-European differences are probably even more pronounced.

Given this considerable leeway, both positive and negative discrimination become viable in a federal system if the preferences of the cantonal and federal authorities differ. Our analysis of the ways in which cantons can employ their considerable discretion is based on the assumption that some states want to use their power in either a liberal or a restrictive fashion. In the next section, we develop a theoretical framework that incorporates all the relevant steps of the procedure.

5. We will test this assumption below.

6 . The duration of the procedure is measured as the number of days from the registration of the refugee in one of the six federal asylum centers until the FOR decides on the asylum claim. Since the time spent on the final decision varies considerably from case to case, the duration differences should be interpreted carefully. 
TABLE 3

Recognition Rates, Shares, and Average Durations by Cantons

\begin{tabular}{|c|c|c|c|c|c|}
\hline Cantons & $\begin{array}{l}\text { Positive } \\
\text { Decisions }\end{array}$ & $\begin{array}{l}\text { Negative } \\
\text { Decisions }\end{array}$ & $\begin{array}{c}\text { Recognition } \\
\text { Rate }^{\mathrm{a}}\end{array}$ & Share ${ }^{\mathrm{b}}$ & $\begin{array}{l}\text { Average } \\
\text { Duration }^{\mathrm{c}}\end{array}$ \\
\hline Aargau & 912 & 12,878 & 6.61 & 7.54 & 335 \\
\hline Appenzell Innerrhoden & 45 & 355 & 11.25 & 0.22 & 237 \\
\hline Appenzell Ausserrhoden & 109 & 1,351 & 7.47 & 0.80 & 295 \\
\hline Bern & 1,769 & 23,956 & 6.88 & 14.07 & 400 \\
\hline Basel Landschaft & 514 & 5,712 & 8.26 & 3.41 & 411 \\
\hline Basel Stadt & 310 & 4,368 & 6.63 & 2.56 & 321 \\
\hline Fribourg & 394 & 5,400 & 6.80 & 3.17 & 318 \\
\hline Genève & 659 & 9,334 & 6.59 & 5.47 & 342 \\
\hline Glarus & 106 & 917 & 10.36 & 0.56 & 346 \\
\hline Graubünden & 351 & 4,707 & 6.94 & 2.77 & 291 \\
\hline Jura & 158 & 1,733 & 8.36 & 1.03 & 303 \\
\hline Luzern & 688 & 7,733 & 8.17 & 4.61 & 381 \\
\hline Neuchâtel & 286 & 4,250 & 6.31 & 2.48 & 359 \\
\hline Nidwalden & 105 & 741 & 12.41 & 0.46 & 278 \\
\hline Obwalden & 78 & 637 & 10.91 & 0.39 & 310 \\
\hline St. Gallen & 758 & 10,313 & 6.85 & 6.06 & 356 \\
\hline Schaffhausen & 167 & 1,847 & 8.29 & 1.10 & 340 \\
\hline Solothurn & 450 & 5,879 & 7.11 & 3.46 & 421 \\
\hline Schwyz & 292 & 2,456 & 10.63 & 1.50 & 387 \\
\hline Thurgau & 322 & 4,621 & 6.51 & 2.70 & 347 \\
\hline Ticino & 361 & 6,413 & 5.33 & 3.70 & 365 \\
\hline Uri & 67 & 818 & 7.57 & 0.48 & 327 \\
\hline Vaud & 977 & 14,773 & 6.20 & 8.61 & 393 \\
\hline Valais & 337 & 6,225 & 5.14 & 3.59 & 341 \\
\hline Zug & 239 & 1,944 & 10.95 & 1.19 & 371 \\
\hline Zürich & 2,471 & 30,553 & 7.48 & 18.06 & 488 \\
\hline Total & 12,925 & 169,914 & 7.07 & 100.00 & 386 \\
\hline
\end{tabular}

a. Recognition rates are defined as the percentage of positive first decisions in relation to all first decisions. b. Share of total applications corresponds approximately to the cantonal quotas.

c. The average duration is measured in days from the date at which an application is officially filed to its first decision.

\section{THE PITFALLS OF FEDERALISM IN ASYLUM POLICY IMPLEMENTATION}

The problems that may arise in the federalist handling of the asylum procedure are twofold. First, the implementation of federal programs on the state level can lead to unintended side effects that systematically undermine the functioning of a program. Second, the delegation of power to a bureaucracy can adversely affect the policy outcome and create inefficient externalities. Both eventual consequences of power delegation to subterritorial units are not new to political scientists. Pressman and Wildavsky (1973) classically summarized the tension between policy makers and agents under the title Implementation: How Great Expectations in Washington Are 
Dashed in Oakland or, Why It's Amazing That Federal Programs Work at All. Niskanen (1971) already earlier had shown that bureaucratic inefficiencies make complete sense if one assumes administrations pursuing their own goals. The two volumes initiated a broad literature that increasingly focuses on the delegation of implementing powers to bureaucracies (see, for example, Calvert, McCubbins, and Weingast, 1989, or Epstein and O'Halloran, 1994, forthcoming, and the literature cited therein). Most of these contributions discuss the implications of agency discretion, that is, the bureaucracy's ability to alter policy outcomes according to its preference. ${ }^{7}$

Although delegation can help politicians to avoid the inefficiencies of legislative decision making, it also comes at the price of "bureaucratic drift." In the context of decentralized asylum policy implementation, this eventual discrepancy between the goals of the federal principal and its agents at the state level is equivalent to discrimination. We know since Becker's (1965) path-breaking work that such behavior is only possible in a system of imperfect competition. A distorted market exists in the domain of asylum policy making because refugees are largely made dependent on a monopoly bureaucracy. Unless they prefer the uncertainty of illegality, they have no possibility to avoid the discriminatory potential of the state, which is in charge of their claim.

Decentralized systems also can lead to negative discrimination in the asylum domain as a consequence of the externalities that stem from the activities of lower tier governments. Although these administrations possess an incentive to export local problems, they tend equally to profit from the benefits that other districts create (McKinnon and Nechyba 1997, 8). A negative externality arises in the asylum domain if state officials shorten the stay of the individual asylum seeker or exclude refugees from social welfare programs to cut down costs. Simultaneously, some states might rely on the generosity of other regions to mask the overrestrictive content of their own measures. If lower tier governments were independent, a race to the bottom could emerge as a possible consequence of the negative externalities. Central governments can counter this kind of competition through financial transfers that compensate states for the costs of the asylum procedure. Another possibility is the introduction of oversight mechanisms. However, such measures might not be sufficient. There is a growing literature that criticizes other salient aspects of decentralization, demonstrating formally that federal solutions might be more efficient. In this vein, some authors stress the advantages of centralized authorities to provide collective goods (Bendor and Mookherjee 1987), emphasize the tendency of subnational agents to establish local rather than global optima (Kollman, Miller, and Page 1997), or claim that centralization can mitigate moral hazard problems (Persson and Tabellini 1996).

Obviously, there also are external effects that should favor the introduction of decentralized rules. The classic argument by Tiebout (1956) states that competition between subtier governments helps individuals in their selection of political jurisdictions in which their personal taste is, by and large, met. Note, however, that this argument does not hold in the context of asylum policy making because asylum seekers do

7. Calvert, McCubbins, and Weingast (1989) give a stringent definition of agency discretion: "agency discretion occurs when the agency succeeds in choosing a policy in line with agency goals, when those goals differ from what the executive and legislature expected at the appointment stage" (p. 605). 
not typically possess the liberty to settle down wherever they like. On the contrary, most nation-states restrict the mobility of asylum seekers considerably. In Switzerland, the federal state decides where claimants have to live during their stay.

The most important argument against the classical externality effect that fiscal federalists attribute to federal solutions is, however, that they might endanger the equity considerations that are important to a majority of a country's population. Koritansky (1987) argues accordingly that "administrative decentralization can be a cover for inequalities and perhaps inequities that may exist between different administrative units" (p. 179). ${ }^{8}$ Riker $(1964,152-53)$ writes in his classic treatise on U.S. federalism that the main beneficiaries of power delegation to the states have been the southern whites. He concludes with the sentence, "Thus, if in the United States one disapproves of racism, one should disapprove of federalism" (p. 155). Some recent studies reiterate this point. Shapiro (1995) analyzes in a legal treatise the situation of minorities in the United States and writes, "national power has had to be continually invoked in order to protect our freedoms against state infringement" (p. 56). Peterson (1995) goes a step further and argues that state legislatures still deserve the reputation of being largely unable "to protect the interests of the disadvantaged" (p. 146).

Most defenders of federal solutions do not explicitly consider the possibility of discrimination. On the contrary, they are largely concerned with the flexibility of federal systems and believe that decentralized policy making is more efficient than centralized decision making. ${ }^{9}$ One particularly pertinent example is Schneider (1998) who believes that a federal EU will necessarily provide more efficient solutions than a centralized version. This optimism stems largely from the literature of fiscal federalism, which stresses in the Tiebout (1956) tradition the benefits of tax competition (Oakes 1972). Other arguments in favor of decentralization are that this system protects minorities, shortens the distance between citizens and government, and offers more possibilities for political participation (Nüssli 1985, 12-13).

The solution that Switzerland has chosen for the implementation of its asylum law is based partly on the principle of subsidiarity. The Swiss government originally preferred to allocate the power in the asylum domain to the federation, not the least with the argument that only such a centralization guarantees a uniform application of the law in the entire country (Bundesrat 1977, 112). This intention is, however, in stark contrast with a recent study. Parini $(1996,172)$ demonstrates that the competence of the cantons gradually has been growing, not the least in the reception of asylum seekers, the audition and preparation of the final decision, as well as the expulsion of denied asylum seekers. One important step toward decentralized decision making was undertaken in 1988 when the central authorities were empowered to decide on asylum claims with the cantonal files as the sole base. ${ }^{10}$ This supports our claim that state agents possess considerable power over individual decisions.

8. See, for example, Höpflinger and Wyss (1993) or Howse (1995).

9. In this sense, Frey and Bohnet (1993) state that "federal competition serves as a safeguard against decisionmakers taking unfair advantage of their discretionary power" (p. 78).

10. For a more detailed description, see Frey (1988) and Ramos (1990). The standard legal textbooks are Kälin (1990) and Achermann and Hausamman (1991). 
A further important change was the introduction of a quota that distributed asylum seekers to the 26 cantons according to the size of the population. Since 1988, each canton has to take a certain percentage of asylum seekers. Because the size of the cantons varies considerably, this burden-sharing quota ranges from $0.2 \%$ to $17.9 \%$ for the smallest and biggest canton, respectively."

We assume in the following that eventually changing reasons of flight cannot fully explain the dramatic decline in the relative number of admissions from more than $90 \%$ in the early 1980 s to less than $10 \% 10$ years later. We rather consider the recognition rate as a policy variable that both the federal and the cantonal authorities seek to alter according to specific political constraints. ${ }^{12}$

\section{HYPOTHESES AND RESEARCH DESIGN}

The double question of this article is whether asylum applicants with a similar background systematically experience positive or negative discrimination in certain states and whether political variables influence these eventual tendencies. Obvious differences in the treatment of asylum seekers across cantons find their expression in a varying likelihood of acceptance. Data on the dependent variable as well as the personal background of the applicants are derived from the official statistics of the Swiss FOR (database AUPER 2) ${ }^{13}$ We transformed this unique resource in a way that allows the analysis with conventional statistical packages. We confine the statistical analysis to the period from 1988 to 1996 because the legal procedure was changed at the beginning of 1988. To empirically investigate our research questions, we estimate logistic regressions for the likelihood that an application is approved.

Four models are built to distinguish between the political, economic, and social factors that affect the recognition rate. The first model analyzes whether the differences in the odds for cantonal recognition rates persist when we control for the sociodemographic background of the claimant as well as the duration of the unappealed procedure and the date of decision. This initial step should allow us to judge whether the variation in the cantonal recognition rates can be attributed to a possibly different composition of the asylum seekers' population across cantons. We expect that the composition of the asylum seekers' population in a canton cannot fully explain the different likelihood of a positive decision. Because we estimate the likelihood for a positive decision by means of logistic regressions, model 1 takes the following functional form:

11. Prior to 1988, asylum seekers could choose the canton that would be in charge of the application through the selection of the place where they would file the original request. The burden was consequently shared in a very unequal manner among the cantons.

12. The number of monthly applications and the recognition rate are positively related with a lag of 7 months for the period between 1986 and 1995 (Holzer, Schneider, and Widmer, forthcoming).

13. AUPER stands for Automatisches Personenregistratursystem (automatic system for registering persons). 


$$
\begin{aligned}
P_{i}=\frac{e^{V_{i}}}{1+e^{V_{i}}} & \text { with } V_{i}=\beta_{0}+\sum_{k=i}^{26} \beta_{k} \cdot \text { cant }_{k i}+\beta_{27} \bullet \text { age }_{i}+\beta_{28} \bullet \operatorname{sex}_{i} \\
& +\beta_{29} \bullet \text { mar }_{i}+\beta_{30} \bullet \text { date }_{i}+\beta_{31} \bullet \text { dur }_{i}+\sum_{j=32}^{38} \beta_{j} \bullet \text { orig }_{j i}
\end{aligned}
$$

where $P_{i}$ expresses the likelihood of a positive decision, $\beta_{0}$ is the constant, and cant $_{k}$ are dummies for the cantons in charge of the procedure. The claimant's age is measured in years, sex is a dummy variable that takes the value 1 if the claimant is female, mar is a dummy variable that takes the value 1 if the claimant is married, date stands for the date of decision, ${ }^{14}$ dur means the duration in days of the asylum procedure, and orig $_{j}$ are dummies for the claimants' most important countries of origin. ${ }^{15}$ Because 2,183 applications have been decided by the federal authorities without the involvement of any canton, we chose these requests as our baseline and include accordingly dummies for all 26 cantons. We hypothesize that there are cantons with either a taste for positive or negative discrimination. Our hypothesis is sustained if we find cantonal dummies significantly different from zero.

Albeit the influence of the controls is not our main interest, we nevertheless want to formulate some hypotheses on their expected impact on the likelihood of acceptance. We first assume that the opportunity costs of flight increase with a potential refugee's age. Younger people have consequently a higher propensity to migrate than the generation of their parents and grandparents. The same relationship holds true if we compare male asylum seekers with female refugees because gender discrimination should theoretically increase the threshold to leave the country of origin; we therefore conclude that women are less likely to migrate than men. A similar distinction separates singles from married people who have to coordinate the flight with at least one other person and therefore have a lower potential for migration. The typical refugee is accordingly a young, single male. Such asylum seekers have, however, the disadvantage of matching the prejudice of an economic refugee perfectly. We consequently expect that male asylum seekers have a lower chance for approval than females. The same effect holds true for single claimants compared with married ones. We finally expect the age of a claimant to be positively related to the likelihood of recognition.

The second model is more structural and intends to show which groups of cantons discriminate positively or negatively. With regard to these more political variables, we have made a distinction between the linguistic group to which a canton belongs. Results from different votes on antiimmigration issues have shown that the Frenchspeaking cantons of Switzerland have a more favorable attitude toward foreigners than the rest of the country (Widmer and Buri 1992). The behavior of cantonal authorities toward asylum seekers is likely to reflect the people's attitude to a certain degree because governments in the Romandie will have greater chances to recruit liberal-minded people for the preparation of the asylum judgment. ${ }^{16}$ A second variable 1960.

14. The date variable is coded in SAS format, that is, is defined as the number of days since January 1 ,

15. These are ex-Yugoslavia, Turkey, Sri Lanka, Lebanon, Pakistan, Somalia, and Romania.

16. Some findings show that French-speaking cantons have adopted less restrictive measures for the labor market access of refugees (Spörndli, Holzer, and Schneider1998). 
that the political culture of the canton at least indirectly describes is its population size. Small states vote typically quite conservatively in national referendums. The rural structure of some of these states makes the whole asylum procedure simultaneously less impersonal. Civil servants who interview asylum seekers in some very small cantons are more concerned with the fate of the refugees because they know them most likely on a personal basis. In very large cantons with urban centers, by contrast, the procedure is, conversely, anonymous. Because large cantons prepare the decision for a far larger number of asylum cases than small ones, the former's impact weighs heavier in logit estimation. ${ }^{17}$ In model 2 , we expect that population size is positively linked to the chance of recognition.

Two further independent variables are the share of the foreign resident population in a canton and the share of "no" votes to a popular initiative that demanded severe restrictions in the asylum law. We use this latter predictor as a proxy for the intensity of negative attitudes toward asylum seekers. The higher the share of no votes, the more tolerant the resident population is toward refugees. The effect of the share of the foreign population is more ambiguous. Obviously, a large share of foreigners makes contacts between immigrants and the holder of a Swiss passport more likely. This can either diminish negative prejudices against foreigners in general and asylum seekers in particular or, in the case of negative experiences, enhance them. In our view, the positive aspects should prevail, and the multicultural cantons should be more tolerant than the states in which the share of foreigners is small.

Finally, we include dummies that relate to ways in which the states organize their asylum administration. The first variable distinguishes cantons with a centralized administration from those that involve the communes. The second one accounts for the fact that cantons can either organize the accommodations for refugees by themselves or delegate at least some aspects to a nonprofit organization. Involving the communes or nonprofit organizations has proven beneficial for all persons involved in the asylum domain, not the least for the asylum seekers themselves. ${ }^{18}$ We assume that these forms of delegation have a positive effect on the odds of approval.

We operationalize the structural variables in the following way: Language (lang) is a dummy that takes the value 1 if French is the main language spoken in the canton and 0 otherwise. ${ }^{19}$ Size refers to the number of inhabitants of a state. Share of foreign population (foreig) measures the share of nonnative inhabitants relative to the overall population, and share of no votes (vote) stands for opposition to the popular initiative. Centralization takes the value of 1 if the communes are not involved in the asylum system of a canton and 0 otherwise. Government ( $g o v$ ) is coded 1 if the canton runs the asylum

17. A general feature of our analysis is the unequal weight of the cantons because the number of decisions per canton varies considerably. But because our argument is based on individual asylum claims, it would be wrong to run regressions of the aggregate of the 26 cantons.

18. This is one of the main results of a research seminar held at the University of Bern during the winter term of 1996. A group of political science students interviewed both asylum seekers and officials in different asylum centers. See Holzer and Schneider (forthcoming).

19. The two bilingual cantons Fribourg and Valais were attributed to the French-speaking cantons, the Italian-speaking Ticino to the German ones. This reflects voting results of these cantons on immigration issues. 
centers and 0 if it delegates this task to a nonprofit organization. We thus estimate the following equation in our test of model 2:

$$
\begin{aligned}
P_{i} & =\frac{e^{V_{i}}}{1+e^{V_{i}}} \text { with }_{i}=\beta_{0}+\beta_{1} \cdot \text { lang }_{i}+\beta_{2} \bullet \text { size }_{i}+\beta_{3} \bullet \text { foreig }_{i} \\
& +\beta_{4} \bullet \text { vote }_{i}+\beta_{5} \bullet \text { centr }_{i}+\beta_{6} \bullet \text { gov }_{i}+\beta_{7} \cdot \text { age }_{i}+\beta_{8} \bullet \text { sex }_{i} \\
& +\beta_{9} \bullet \text { mar }_{i}+\beta_{10} \bullet \text { date }_{i}+\beta_{11} \bullet \text { dur }_{i}+\sum_{j=12}^{18} \beta_{j} \bullet \text { orig }_{j i} .
\end{aligned}
$$

The third and fourth model include both interaction effects and nonlinear coefficients in which such a relationship seems adequate. Whereas the third model builds on model 1 , model 4 extends model 2 . To start with the structural variations, model 4 incorporates the squared population size of the cantons and an interaction effect between the share of the foreign population and the magnitude of negative feelings toward foreigners. The impact of negative feelings in the population toward asylum seekers should, in our view, be more important in cantons with a high proportion of foreigners. With regard to size, we expect that both very small and very large states are associated with higher recognition rates than middle-sized ones. Furthermore, we measure negative feelings in the population toward foreigners by the average approval to antiforeigner issues in nine popular votes instead of one popular initiative only. ${ }^{20}$

It is also quite likely that the effect of age and marital status on the chances of approval depends on the claimant's gender. Because women generally face better chances for recognition, we expect the impact of age and marital status to be smaller for females than for males. Moreover, models 3 and 4 assume a U-shaped relationship between the claimant's age and her chances for recognition. Accordingly, very young asylum seekers (children) and elderly claimants have a higher likelihood of acceptance than middle-aged ones. Moreover, this effect is supposed to be larger for males than for females; that is, the parabola relating the odds for recognition to age is steeper for males than for females. Similarly, the positive effect of the variable marital status is supposed to be larger for males than for females.

Our expectations are more ambiguous with regard to the date of the decision and the duration of the procedure. The figures in Table 1 indicate a drop in the recognition rate from $7 \%$ to $3 \%$ at the beginning of our period of investigation. The recognition rate raises then to $15 \%$. This positive linear impact of the date of decision on the recognition rate is weakened by the fact that, in the years with low recognition rate, a greater number of applications have been decided. To overcome this ambiguity, we include a nonlinear coefficient for the date of the decision. In addition, it seems quite implausible that the date of decision affects the likelihood for a positive decision for all asylum

20. The nine votes include a new foreigner law (June 6, 1982), a popular initiative "against the sellout of the home country" (May 20,1984), a revision of the foreigner law (April 5, 1987), a revision of the asylum law (April 5, 1987), a popular initiative "for the restriction of immigration" (December 4, 1988), a law on the naturalization of young foreigners (June 12,1994), a law on the prohibition of racial discrimination (September 25, 1994), a revision of the law on the purchase of real estate by foreigners (June 25, 1995), and a popular initiative "against illegal immigration" (December 1, 1996). 
TABLE 4

Cantonal Attributes and Their Expected Impact on the Chance of Acceptance

\begin{tabular}{|c|c|c|c|c|}
\hline Variable & Model 1 & Model 2 & Model 3 & Model 4 \\
\hline Cantonal dummies & both + and - & & both + and - & \\
\hline Language & & + & & + \\
\hline Size & & + & & - \\
\hline Size squared & & & & + \\
\hline Foreigners & & $+/-$ & & $+/-$ \\
\hline Tolerance toward asylum seekers & & + & & + \\
\hline Interaction foreigners & & & & + \\
\hline \multicolumn{5}{|l|}{ Tolerance toward asylum seekers } \\
\hline Centralization & & - & & - \\
\hline Government & & - & & - \\
\hline
\end{tabular}

seekers in the same way. The effect of the date of decision most likely depends also on the claimant's country of origin. We therefore include interaction terms between the date of decision and the three most important sender nations, namely, the former Yugoslavia, Turkey, and Sri Lanka. Due to the developments in Turkey and especially in the former Yugoslavia, we expect the U-shaped relationship to be inverted for these two countries. Moreover, the effect is supposed to be larger in the former Yugoslavia.

We omit the presentation of the specifications of models 3 and 4 because their basic structure is identical to those of models 1 and 2 . Table 4 summarizes our expectations about the signs of the parameter estimates for the cantonal variables.

\section{A QUANTITATIVE ASSESSMENT OF DISCRIMINATION IN DECENTRALIZED ASYLUM POLICY MAKING}

In the 10-year period from 1986 to $1996,208,754$ asylum applications were put forward in Switzerland. The inflow of refugees has, however, not been constant during the entire time under observation. A peak was reached in the early 1990s just before unilateral deterrence measures in the form of severe restrictions in the modified asylum law became effective (Holzer, Schneider, and Widmer forthcoming). During the period under observation, the average refugee was a single, 24-year-old male. Only $26.3 \%$ of all asylum applicants were females, and approximately $40 \%$ of all refugees were married. A total of $62.4 \%$ of those 162,386 asylum seekers who identified with a certain religion during the interrogations were Muslims; $21.7 \%$ were Christians; and $11.9 \%$ were Hindu. Shiks (2.2\%), Buddhists (0.5\%), and Jews (0.1\%) represented relatively small minorities.

Only $7.1 \%$ of all applications were accepted. Whereas the federal authorities rejected $50.4 \%$ of all cases directly, they did not take $27.5 \%$ into consideration, and $14.9 \%$ fell into the category of those requests that did not have to be treated in the end. Nondecisions were, for instance, a consequence of the departure or the death of an 
TABLE 5

Number of Applications: Recognition Ratio and Average Duration by Country of Origin, 1986 to 1996

\begin{tabular}{|c|c|c|c|c|}
\hline $\begin{array}{l}\text { Region/Country } \\
\text { of Origin }\end{array}$ & $\begin{array}{c}\text { Number of } \\
\text { Decisions }\end{array}$ & $\begin{array}{l}\text { Relative Share } \\
\text { in Percentages }\end{array}$ & $\begin{array}{l}\text { Recognition } \\
\text { Rate }\end{array}$ & $\begin{array}{l}\text { Average } \\
\text { Duration }\end{array}$ \\
\hline \multicolumn{5}{|l|}{ Europe } \\
\hline Ex-Yugoslavia & 51,753 & 25.4 & 12.63 & 231 \\
\hline Turkey & 46,049 & 22.7 & 8.98 & 383 \\
\hline Romania & 6,201 & 3.1 & 2.05 & 190 \\
\hline Albania & 4,310 & 2.1 & 0.84 & 147 \\
\hline Ex-Soviet Union ${ }^{\mathrm{a}}$ & 638 & 0.3 & 0.78 & 141 \\
\hline Rest Europe & 4,148 & 2.0 & 5.74 & 176 \\
\hline \multicolumn{5}{|l|}{ Africa } \\
\hline Somalia & 6,333 & 3.1 & 1.31 & 281 \\
\hline Angola & 5,488 & 2.7 & 0.13 & 366 \\
\hline Zaire & 5,339 & 2.6 & 1.01 & 297 \\
\hline Ghana & 2,290 & 1.1 & 0.00 & 397 \\
\hline Algeria & 2,232 & 1.1 & 0.58 & 124 \\
\hline Rest Africa & 8,705 & 4.3 & 0.05 & 337 \\
\hline \multicolumn{5}{|l|}{ Asia } \\
\hline Sri Lanka & 22,315 & 11.0 & 1.16 & 1,059 \\
\hline Lebanon & 11,391 & 5.6 & 0.15 & 409 \\
\hline Pakistan & 7,036 & 3.5 & 2.15 & 286 \\
\hline India & 4,826 & 2.4 & 0.25 & 267 \\
\hline Iran & 3,130 & 1.5 & 11.25 & 627 \\
\hline Bangladesh & 3,039 & 1.5 & 0.33 & 356 \\
\hline Rest Asia & 6,521 & 3.2 & 32.59 & 393 \\
\hline Americas & 1,555 & 0.8 & 13.12 & 337 \\
\hline Total & 203,281 & 100 & - & - \\
\hline Missing & 5,473 & - & - & - \\
\hline
\end{tabular}

a. Included because asylum seekers could not properly be attributed to either Asia or Europe.

applicant. Applications also can fall into this category if a legal judgment did not find what is described as an "objective" reason for the asylum claim. Unfortunately, the data at our disposal do not allow us to distinguish between different forms of behavior within this residual category.

As Table 5 shows, the recognition rate and average duration of the procedure vary considerably across nations. The average recognition ratio of European refugees, especially from ex-Yugoslavia and Turkey, is much larger than the corresponding figures for Asian or African asylum seekers. The extremely high recognition rate of the category "Rest Asia" is due to the relatively generous attitude of the Swiss authorities toward Vietnamese refugees; this attitude might reflect an anti-Communist bias that stems from the cold war and was quite common in the OECD world (Joppke 1997; Miles and Thränhardt 1995). Asylum seekers from this far eastern country have experienced a recognition rate of more than $80 \%$. Another interesting feature is the very 
long duration of Sri Lankan applications. This may partly explain the high number of applications despite the low recognition rate.

Differences in the average duration of the procedure and the recognition rate of refugees from various sender countries are, however, not a convincing confirmation that asylum policy implementation is an area with a huge potential for discrimination. Obviously, people from different countries of origin might have different reasons for trying to become recognized refugees. Different durations may, for instance, be due to difficulties in obtaining the relevant information about the situation in some countries or for some refugee groups.

To fill the empirical gap, we present a test of the discriminatory potential in a political system that has delegated a considerable amount of power in the asylum law to subterritorial units (see the table in the appendix for the full estimation results). The preliminary analysis (model 1) unambiguously shows that the probability of approval of an asylum request is highly influenced by the canton in charge, even if we control for the different composition of the asylum seekers' populations in the cantons.

According to the estimation results of model 1, six cantons significantly discriminate negatively, and five cantons have a significant taste for positive discrimination. The impact of the cantons on the recognition rate is thus important. Because 13,040 applications were approved and 172,750 requests were rejected in the period from 1988 to 1996, the odds for a positive decision are without further information 0.075. In other words, out of 1,075 decisions, 75 are positive and 1,000 are negative. ${ }^{21}$ The odds ratio indicates the factor by which the odds for a positive decision are changed due to a one-unit change in the independent variable. For example, the odds ratio of 0.661 of the canton of Ticino, the only predominantly Italian-speaking canton, means that the odds of a positive decision in this canton are $0.075 \times 0.661=0.050$. In other words, out of 1,050 applications that haven been treated by this canton, 50 were decided in favor of the applicant. The canton with the highest odds ratio is the small and relatively rural canton of Nidwalden. ${ }^{22}$ The odds for a positive decision are 0.115 there. Ceteris paribus, the probability of a positive decision in Ticino is $4.8 \%$ compared with $10.3 \%$ in Nidwalden.

The results obtained from the estimation of equation 1 show that the variance in the likelihood of being accepted as a refugee among the cantons did not decrease after controlling for the composition of the asylum seekers' population. But two cantons with above-average recognition rates in Table 3 have odds ratios less than 1 (i.e., discriminate negatively if the coefficient for the cantonal dummy is statistically different from 0 ), and five cantons with below-average recognition rates in Table 3 have odds ratios greater than 1 . This indicates that the composition of the asylum seekers' population should not be neglected. Yet, the discriminatory potential of the cantons is even more

21. The odds are defined as $O_{i}=P_{i} /\left(1-P_{i}\right)$, in which $P_{i}$ denotes the probability of the occurrence of the event. The probability can be retrieved from the odds as $P_{i}=O_{i} /\left(1+O_{i}\right)$. The odds ratios $O R_{i}$ are defined as $\exp \left(\beta_{\mathrm{i}}\right)$, and $O_{i} \times O R_{i}$ indicates the change in the odds induced by a one-unit change in the independent variable. The impact of an $n$-unit change in the independent variable on the odds is given by $O_{i} \times O R_{i}{ }^{n}$.

22. Formally, Nidwalden is a so-called semicanton, which only can send one deputy to the upper federal chamber. Full cantons, by contrast, are entitled to elect two politicians to this Senate-like institution. 
pronounced with the more realistic structure of the third model. Seven cantons have a significant taste for negative discrimination; five cantons, conversely, discriminate positively. The probabilities for a positive decision in the most extreme cases are now $10.7 \%$ (Nidwalden) and $4.5 \%$ (Ticino). This further indicates that the main hypothesis is confirmed. The different cantonal recognition rates can accordingly not be explained by the populations of asylum seekers but stem from factors that we consider discriminatory.

To address the question of whether other organizational features in federalist Switzerland lead to discrimination, we estimated two additional models for the period from 1992 to $1996 .^{23}$ The first refers to the organizational structure of the central authority, which is divided into 16 sections. Each section is responsible for deciding the claims from certain countries of origin that were handled in certain cantons. The second additional model takes into account that each asylum seeker is registered in one of the eight centers run by the central authority, in which a first short interview takes place before the claimants are allocated to a canton. A comparison between these alternative models and the one with the cantonal dummies suggests that these additional federalist organizational principles could account for some part of the discrimination against asylum seekers among the cantons. Unfortunately, there is high multicollinearity between the cantonal responsibility and the asylum centers under central authority. Moreover, the question of which section of the FOR takes the final decision is contingent on the responsibility of the cantons and the claimants' country of origin. It is therefore impossible to estimate a model that includes all of these variables simultaneously. We decided to discuss the cantonal model in length because we believe that it gives the most interesting implications.

To account for discrimination against specific types of individuals, we estimated the logistic model 1 for each canton separately by omitting the dummy variables. Whereas most cantons fit the general pattern, there are some striking exceptions. In the canton of Appenzell Innerrhoden, the odds of a positive decision increase from 0.12 to 0.99 if the applicant is female. Equivalently, these odds drop to 0.02 if the applicant is male. ${ }^{24}$ Whereas in Basel Landschaft, the odds for a positive decision increase from 0.09 to 0.93 for Turkish asylum seekers, the odds decrease in Glarus from 0.11 to 0.006 . This is an example of positive and negative discrimination that asylum seekers of a specific origin have to endure. The canton of Fribourg, on the other hand, strongly discriminates against Sri Lankan applicants. The odds for a positive decision of 0.07 decrease to 0.006 if an asylum seeker comes from this country. In contrast to the general pattern, applicants from ex-Yugoslavia have a less than average chance of acceptance in the canton of St. Gallen. The corresponding odds ratio amounts to 0.973.

A more systematic analysis of the canton's impact on asylum decisions asks for the inclusion of canton-specific independent variables instead of simple dummies. As we outlined in the previous section, we consider the cultural affiliation, population size,

23. We had to shorten the period because we do not possess the data for the additional models prior to 1992. We do not present these and the subsequent estimation results to save space, but they can be obtained from the authors on request.

24. The implications of this result should not be exaggerated because this canton was responsible for about 400 applications only. 
TABLE 6

The Impact of the Cantonal Attributes on the Likelihood of a Positive Decision

\begin{tabular}{|c|c|c|}
\hline & Model 2 & Model 4 \\
\hline Intercept & $\begin{array}{l}-13.3149^{* * *} \\
(-61.70)\end{array}$ & $\begin{array}{l}70.4442^{* * * *} \\
(17.61)\end{array}$ \\
\hline Language & $\begin{array}{c}-0.0296 \\
(0.60) \\
0.971\end{array}$ & $\begin{array}{c}-0.0577 \\
(-0.97) \\
0.944\end{array}$ \\
\hline Size & $\begin{array}{l}4.116 \mathrm{E}-8 \\
(1.22) \\
1.000\end{array}$ & $\begin{array}{l}-9.3 \mathrm{E}-7 * * * \\
(-6.75) \\
1.000\end{array}$ \\
\hline Size squared & - & $\begin{array}{l}8.04 \mathrm{E}-13 \text { *** } \\
(7.31) \\
1.000\end{array}$ \\
\hline Share of foreign population & $\begin{array}{c}-0.4658 * \\
(-2.27) \\
0.628\end{array}$ & $\begin{array}{l}-19.8706 * * * \\
(-8.52) \\
0.000\end{array}$ \\
\hline Share of "no" votes to popular initiative ${ }^{a}$ & $\begin{array}{l}0.00876^{* * * *} \\
(3.11) \\
1.009\end{array}$ & $\begin{array}{l}-0.0568 * * * \\
(-5.07) \\
0.945\end{array}$ \\
\hline Share of foreigners $\times$ Share of No Votes ${ }^{a}$ & - & $\begin{array}{l}0.3644 * * * \\
(8.40) \\
1.440\end{array}$ \\
\hline Centralization & $\begin{array}{c}-0.1068^{*} \\
(-3.07) \\
0.899\end{array}$ & $\begin{array}{c}-0.0447 \\
(-0.98) \\
0.956\end{array}$ \\
\hline Government & $\begin{array}{c}-0.0114 \\
(-0.46) \\
0.989\end{array}$ & $\begin{array}{c}-0.00936 \\
(-0.36) \\
0.991\end{array}$ \\
\hline \multicolumn{3}{|l|}{ Diagnostics } \\
\hline Chi-square & $\begin{array}{r}12,429.045 \\
(18 d f)\end{array}$ & $\begin{array}{r}20,281.790 \\
(31 d f)\end{array}$ \\
\hline Gamma & 0.579 & 0.682 \\
\hline Concordant pairs (\%) & 78.4 & 83.6 \\
\hline$N$ & 181,100 & 181,100 \\
\hline
\end{tabular}

NOTE: Entries are unstandardized parameter estimates, $t$-statistics in parentheses, and odds ratios. If the odds ratio is smaller than 1 , an increase in the independent variable decreases the probability of a positive decision, everything else being equal. In the event that it is larger than 1 , the probability of the event increases. A value of 1 leaves the odds unchanged. The outcome variable takes the value 1 if an asylum application is accepted (0 otherwise).

a. In model 4 , this variable refers to the average number of "no" votes.

$* p<.05 . * * p<.01 . * * * p<.0001$.

share of the foreign population in a canton, share of no votes to the popular initiative (model 2) and nine antiforeigner issues (model 4), and administrative structure as explanatory variables for model 2 . In model 4 , we add an interaction effect and a nonlinear term. The corresponding results are reported in Table 6. 
In contrast to our expectation, French-speaking cantons in charge of an application do not have a significantly positive impact on the likelihood of recognition. This result is probably due to the fact that there is a significant correlation between the linguistic affiliation of a canton and the share of no votes to the popular initiative and the nine antiforeigner issues, respectively. The linear effect of a canton's size, albeit highly significant, is small. An increase in the population of 100,000 inhabitants is associated with an odds ratio of $1.0041 .^{25}$ The positive sign of the coefficient for the squared size in model 4 implies, in line with our expectations, that both very small and very large cantons are associated with higher acceptance rates. This means that increased levels of social communication and anonymity have a positive impact. The share of the foreign population living in a canton has a significantly negative impact on the likelihood of acceptance. In model 2, the positive sign of the coefficient of the popular initiative suggests that the higher the share of no votes in a canton the higher, ceteris paribus, the recognition rate. But this result is not maintained if we include an interaction term between the share of foreigners and the share of no votes to the antiforeigner issues. ${ }^{26}$ The sign of the parameter estimate for the interaction term is positive, as expected, but the sign for the share of no votes points to the opposite direction. The magnitude of the coefficients indicates a reversed relationship of the share of no votes up to a share of foreigners of $18 \% .{ }^{27}$ With regard to the other main predictors, the centralized structure and the delegation of tasks to nonprofit organizations, our expectations are confirmed only to the extent that the coefficient for centralization is significant in model $2 .{ }^{28}$ This means that the active participation of the communes (and probably the resulting loss in anonymity) enhance the likelihood of recognition.

The expectations about the linear impact of the age variable in the first model are not supported by the empirical results. ${ }^{29} \mathrm{~A}$ one-unit increase in the age of the applicant decreases the odds for approval by a factor of 0.979 . This impact does not seem to be important, but a 20 (40) year increase in age leads to an odds ratio of 0.65 (0.43). One possibility to explain this result is the quite large number of children born while their parents waited for the outcome of the asylum procedure. Infants have an above-average chance to be recognized as refugees.

The parameter estimates for both gender and marital status are highly significant, the signs point in the expected direction, and the corresponding odds ratios are well greater than 1 . The probability for a positive decision for a random observation drawn from the sample is $6.98 \%$. With the additional information that the random observation is a female (male) asylum seeker, the probability increases (decreases) to $15.18 \%$ $(3.05 \%)$. For a simple random draw among married persons, the probability for a posi-

25. The size of the cantons varies from 13,870 to $1,179,044$ inhabitants; nine cantons have a population of less than 100,000 inhabitants.

26. This result does not alter if we replace the share of "no" votes to the nine antiforeigner issues by the average share of no votes to the popular initiative.

27. There are 17 cantons with a share of foreigners of less than $18 \%$ and 9 cantons with a share higher than $18 \%$.

28. In a model in which we dropped the popular initiative, however, both coefficients were significant as well as the parameter estimate for the language variable.

29. The numerical effects in the discussion below are calculated from the parameter estimates of model 1. For model 2, these effects are practically identical. 
tive decision is $10.76 \%$, whereas a single individual's chances for approval are $4.46 \%$. With the specification chosen in the first model, we cannot answer the question of whether marital status has the same impact on the chances of approval for both females and males. We come back to this point in the discussion of the third model.

Although the date of decision is highly significant, it does not seem to have a large impact on the dependent variable. It is, however, important to note that the date variable is measured on a daily basis. A thousand-day move toward the end of the investigation period multiplies the odds for a positive decision by the factor 2.3. But it is quite unlikely that the date of decision influences the chances for approval for each individual in the same way. In models 3 and 4 , we assume more realistically that the impact of the date of decision depends on the claimants' country of origin.

The impact of the duration of the procedure is less important. The odds ratio for a 1 -year longer duration is 0.89 . The country dummies reveal that asylum seekers from the former Yugoslavia and especially from Turkey have better chances for approval, whereas claimants originating from Sri Lanka, Lebanon, Pakistan, Somalia, or Romania face a lower probability. Once again, the margin is important. An asylum seeker from Turkey has a $17.94 \%$ probability for approval. For a Lebanese claimant, this probability is only $0.003 \%$. These results can be interpreted in the way that the preconceptions about certain states influence the chance of admission. ${ }^{30}$

In models 3 and 4 , it is important to note that neither the parameter estimates nor the odds ratios for variables with interactions and/or squared terms can be interpreted directly. We want to illustrate the interpretation with the example of the age variable in model 3. ${ }^{31}$ The U-shaped relationship between age and the chances for recognition is confirmed by the significantly positive parameter estimate for the squared age variable. Moreover, this effect is larger for males than females because the coefficient of the interaction effect between gender and age squared is negative but smaller in absolute value than the parameter estimate for age squared. The odds ratios are not constant over the range of the variable because of this nonlinear relationship but depend on the applicant's age. For males, the odds ratio is $\exp (-0.1528+0.00474 \times$ age $)$ and for females $\exp (-0.044+0.00168 \times$ age $)$. The odds ratios for newly born males and females are 0.858 and 0.957 , respectively. A 1 -year increase in age thus decreases the odds for a positive decision by the factor 0.858 for males and 0.957 for females. An increase in age has a negative effect on the odds for recognition until the age of 32 (26) for males (females). Beyond this age, every additional year enhances the chance of a positive decision. Married applicants can expect a higher likelihood of approval than singles. However, the impact for males is almost three times as large as for females.

The empirical results also support our expectations on the impact that the date of decision should have in conjunction with the most important sender nations. Because we included dummies for refugees from the former Yugoslavia, Turkey, and Sri Lanka, the coefficients of the date variables relate to all other nations. The hump-shaped relationship between the date of decision and the odds for recognition are confirmed for

30. The share of immigrants from Turkey and ex-Yugoslavia in the Swiss population is relatively large.

31. All the considerations below are based on the parameter estimates of model 3, which do not substantially differ from those of model 4. 
the former Yugoslavia and Turkey. A plot of the date of decision against the likelihood of recognition would yield a downsidedly open parabola. For the former country, the chances of approval increase until September 1994, reach their maximum value at this date, and start to decrease again afterward. For Turkey, the parabola is much flatter and reaches its maximum value outside the investigation period. The chance of admission for Turkish asylum seekers thus increases with a decreasing rate throughout the investigation period. For Sri Lanka and the other countries, the U-shaped relationship is confirmed by the data, although in model 3 the parameter estimates for Sri Lanka are not significantly different from zero.

\section{CONCLUSION}

This article has shown that the way in which Switzerland delegates power in the asylum domain to the cantons leads to positive and negative discrimination of certain groups of refugees. Although the individual background of a claimant has the strongest influence on the chance of recognition, our results unambiguously support the contention that decentralized implementation might be linked to the unequal treatment of individuals. We furthermore demonstrate that the way in which the asylum administration is organized at the level of the cantons influences the chance of admission. Even more important are the share of the foreign population residing in a state and, in combination with this variable, the attitude of the Swiss citizens toward immigrants and asylum seekers.

Discrimination caused by a federal asylum system is a politically sensitive result insofar as asylum applicants do not possess an exit option that would allow them to flee from a restrictive to a more liberal state. The analysis drawn from the Swiss example suggests that such unfairness might remain a major problem in the EU if it moves closer toward a harmonization of its asylum practices but ultimately fails to establish uniform standards in the ways in which asylum seekers are treated. In our view, decentralized policy making will be one of the main hindrances toward the creation of effective international regimes.

Theoretically, the analysis has confirmed that delegating implementation power to a state can create severe externality problems. The high transaction costs associated with decentralized implementation invites political agents to pursue a course that might differ from the wishes of their federal principals. Our results thus ultimately support the criticism by Riker (1964) and others that decentralized decision making endangers the rights of minorities on some occasions. Although we are far from a comparative analysis of different institutional settings, the results presented in this article suggest at least some caution in our praise of federalism and subsidiarity. 


\section{APPENDIX}

Full Estimation Results of the Impact of the Cantonal Attributes on the Likelihood of a Positive Decision

\begin{tabular}{|c|c|c|c|c|}
\hline & Model 1 & Model 2 & Model 3 & Model 4 \\
\hline Intercept & $\begin{array}{l}-14.3092 * * * \\
(-77.64)\end{array}$ & $\begin{array}{l}-13.3149 * * * \\
(-61.70)\end{array}$ & $\begin{array}{l}55.0283 * * * \\
(14.30)\end{array}$ & $\begin{array}{l}70.4442 * * * \\
(17.61)\end{array}$ \\
\hline Language & $\overline{-}$ & $\begin{array}{l}-0.0296 \\
(0.60)\end{array}$ & $\begin{array}{l}\cdot \\
- \\
0.944\end{array}$ & $\begin{array}{c}\cdot 0.0577 \\
(-0.97)\end{array}$ \\
\hline Size & - & $\begin{array}{l}4.116 \mathrm{E}-8 \\
(1.22) \\
1.000\end{array}$ & - & $\begin{array}{l}-9.3 \mathrm{E}-7 * * * \\
(-6.75) \\
1.000\end{array}$ \\
\hline Size squared & - & - & - & $\begin{array}{l}8.04 \mathrm{E}-13 \text { **** } \\
(7.31) \\
1.000\end{array}$ \\
\hline Share of foreign population & - & $\begin{array}{c}-0.4658 * \\
(-2.27) \\
0.628\end{array}$ & - & $\begin{array}{l}-19.8706^{* * * *} \\
(-8.52) \\
0.000\end{array}$ \\
\hline Share of "no" votes & - & $\begin{array}{l}0.00876 * * \\
(3.11) \\
1.009\end{array}$ & - & $\begin{array}{l}-0.0568 * * * \\
(-5.07) \\
0.945\end{array}$ \\
\hline Share of foreigners $\times$ Share of No Votes & - & - & - & $\begin{array}{l}.3644 * * * \\
(8.40) \\
1.440\end{array}$ \\
\hline Centralization & - & $\begin{array}{c}-0.1068 * \\
(-3.07) \\
0.899\end{array}$ & - & $\begin{array}{c}-0.0447 \\
(-0.98) \\
0.956\end{array}$ \\
\hline Government & - & $\begin{array}{c}-0.0114 \\
(-0.46) \\
0.989\end{array}$ & - & $\begin{array}{c}-0.00936 \\
(-0.36) \\
0.991\end{array}$ \\
\hline AG & $\begin{array}{c}-0.1493^{*} \\
(-2.18) \\
0.861\end{array}$ & - & $\begin{array}{l}-0.1427 * \\
(-2.00) \\
0.867\end{array}$ & - \\
\hline AI & $\begin{array}{l}0.3066 \\
(1.73) \\
1.359\end{array}$ & - & $\begin{array}{c}0.3167 \\
(1.71) \\
1.373\end{array}$ & - \\
\hline AR & $\begin{array}{c}-0.2251 \\
(-1.90) \\
0.799\end{array}$ & - & $\begin{array}{l}-0.2501 * \\
(-2.02) \\
0.779\end{array}$ & - \\
\hline $\mathrm{BE}$ & $\begin{array}{l}0.0416 \\
(0.65) \\
1.043\end{array}$ & - & $\begin{array}{c}0.0444 \\
(0.67) \\
1.045\end{array}$ & - \\
\hline $\mathrm{BL}$ & $\begin{array}{l}0.0411 \\
(0.54) \\
1.042\end{array}$ & - & $\begin{array}{l}0.0109 \\
(0.14) \\
1.011\end{array}$ & - \\
\hline BS & $\begin{array}{l}-0.2934 * * \\
(-3.44) \\
0.746\end{array}$ & - & $\begin{array}{l}-0.3815^{* * * *} \\
(-4.29) \\
0.683\end{array}$ & - \\
\hline
\end{tabular}




\begin{tabular}{|c|c|c|c|c|}
\hline & Model 1 & Model 2 & Model 3 & Model \\
\hline \multirow[t]{3}{*}{ FR } & -0.0187 & & -0.0141 & \\
\hline & $(-0.23)$ & - & $(-0.17)$ & - \\
\hline & 0.981 & & 0.986 & \\
\hline \multirow[t]{3}{*}{ GE } & 0.1026 & & 0.0634 & \\
\hline & $(1.43)$ & - & $(0.85)$ & - \\
\hline & 1.109 & & 1.065 & \\
\hline \multirow[t]{3}{*}{ GL } & 0.1482 & & $0.2776^{*}$ & \\
\hline & (1.18) & - & $(2.15)$ & - \\
\hline & 1.160 & & 1.320 & \\
\hline \multirow[t]{3}{*}{ GR } & -0.1215 & & -0.1674 & \\
\hline & $(-1.47)$ & - & $(-1.94)$ & - \\
\hline & 0.886 & & 0.846 & \\
\hline \multirow[t]{3}{*}{ JU } & 0.1510 & & 0.1107 & \\
\hline & (1.44) & - & $(1.02)$ & - \\
\hline & 1.163 & & 1.117 & \\
\hline \multirow[t]{3}{*}{ LU } & $0.1474 *$ & & $0.1667 *$ & \\
\hline & $(2.04)$ & - & $(2.21)$ & - \\
\hline & 1.159 & & 1.181 & \\
\hline \multirow[t]{3}{*}{$\mathrm{NE}$} & -0.1496 & & -0.1589 & \\
\hline & $(-1.72)$ & - & $(-1.77)$ & - \\
\hline & 0.861 & & 0.853 & \\
\hline \multirow[t]{3}{*}{ NW } & $0.4231^{* *}$ & & $0.4650^{* *}$ & \\
\hline & $(3.40)$ & - & $(3.56)$ & - \\
\hline & 1.527 & & 1.592 & \\
\hline \multirow[t]{3}{*}{ OW } & $0.2812^{*}$ & & $0.3102 *$ & \\
\hline & $(2.00)$ & - & $(2.11)$ & - \\
\hline & 1.325 & & 1.364 & \\
\hline \multirow[t]{3}{*}{ SG } & -0.1137 & & $-0.1716^{*}$ & \\
\hline & (1.61) & - & $(-2.33)$ & - \\
\hline & 0.893 & & 0.842 & \\
\hline \multirow[t]{3}{*}{ SH } & 0.0784 & & 0.1050 & \\
\hline & $(0.75)$ & - & $(0.98)$ & - \\
\hline & 1.081 & & 1.111 & \\
\hline \multirow[t]{3}{*}{ SO } & 0.00173 & & 0.0165 & \\
\hline & $(0.02)$ & - & $(0.20)$ & - \\
\hline & 1.002 & & 1.017 & \\
\hline \multirow[t]{3}{*}{ SZ } & $0.2117^{*}$ & & 0.1756 & \\
\hline & $(2.40)$ & - & (1.90) & - \\
\hline & 1.236 & & 1.192 & \\
\hline \multirow[t]{3}{*}{ TG } & $-0.2111^{*}$ & & $-0.3151^{* *}$ & \\
\hline & $(-2.52)$ & - & $(-3.61)$ & - \\
\hline & 0.810 & & 0.730 & \\
\hline \multirow[t]{3}{*}{ TI } & $-0.4143^{* * *}$ & & $-0.4718^{* * *}$ & \\
\hline & $(-5.10)$ & - & $(-5.56)$ & - \\
\hline & 0.661 & & 0.624 & \\
\hline \multirow[t]{3}{*}{ UR } & -0.1906 & & -0.1259 & \\
\hline & $(-1.32)$ & - & $(0.83)$ & - \\
\hline & 0.826 & & 0.882 & \\
\hline \multirow[t]{3}{*}{ VD } & -0.0683 & & -0.1225 & \\
\hline & $(-1.01)$ & - & $(-1.74)$ & - \\
\hline & 0.934 & & 0.885 & \\
\hline
\end{tabular}




\begin{tabular}{|c|c|c|c|c|}
\hline & Model 1 & Model 2 & Model 3 & Model 4 \\
\hline \multirow[t]{3}{*}{ VS } & $-0.2993^{* *}$ & & $-0.3624 * * *$ & \\
\hline & $(-3.63)$ & & $(-4.24)$ & \\
\hline & 0.741 & & 0.696 & \\
\hline \multirow[t]{3}{*}{ ZG } & $0.2964 * *$ & & $0.2591 * *$ & \\
\hline & $(3.17)$ & - & $(2.65)$ & - \\
\hline & 1.344 & & 1.296 & \\
\hline \multirow[t]{3}{*}{$\mathrm{ZH}$} & 0.0777 & & 0.0790 & \\
\hline & $(1.24)$ & - & $(1.21)$ & - \\
\hline & 1.081 & & 1.082 & \\
\hline \multirow[t]{3}{*}{ Age } & $-0.0203 * * *$ & $-0.0183 * * *$ & $-0.1528 * * *$ & $-0.1506 * * *$ \\
\hline & $(-20.10)$ & $(-17.94)$ & $(-58.32)$ & $(-56.83)$ \\
\hline & 0.979 & 0.982 & 0.858 & 0.860 \\
\hline \multirow[t]{3}{*}{ Age squared } & & & $0.00237 * * *$ & $0.00236^{* * *}$ \\
\hline & - & - & $(49.38)$ & $(48.16)$ \\
\hline & & & 1.002 & 1.002 \\
\hline \multirow[t]{3}{*}{ Gender } & $0.8688 * * *$ & $0.8565 * * *$ & $-0.2703 * * *$ & $-0.2804 * * *$ \\
\hline & $(43.01)$ & (41.99) & $(-6.44)$ & $(-6.57)$ \\
\hline & 2.387 & 2.355 & 0.763 & 0.755 \\
\hline \multirow[t]{3}{*}{ Gender $\times$ Age } & - & - & $0.1084 * * *$ & $0.1098^{* * *}$ \\
\hline & & & $(26.25)$ & $(26.27)$ \\
\hline & & & 1.114 & 1.116 \\
\hline \multirow[t]{3}{*}{ Gender $\times$ Age squared } & & & $-0.00153 * * *$ & $-0.00156^{* * * *}$ \\
\hline & - & - & $(-21.86)$ & $(-21.97)$ \\
\hline & & & 0.998 & 0.998 \\
\hline \multirow[t]{3}{*}{ Marital status } & $0.4748 * * *$ & $0.4419 * * *$ & $0.8902 * * *$ & $0.8678^{* * *}$ \\
\hline & $(18.77)$ & $(17.33)$ & $(24.19)$ & $(23.39)$ \\
\hline & 1.608 & 1.556 & 2.436 & 2.382 \\
\hline \multirow[t]{3}{*}{ Gender $\times$ Marital Status } & & & $-0.5855 * * *$ & $-0.6198 * * *$ \\
\hline & - & - & $(-10.44)$ & $(-10.93)$ \\
\hline & & & 0.557 & 0.538 \\
\hline \multirow[t]{3}{*}{ Date of decision } & $0.00084^{* * *} *$ & $0.000836^{* * *}$ & $*-0.00973 * * *$ & $-0.0118 * * *$ \\
\hline & $(64.62)$ & (59.71) & $(-15.23)$ & $(-17.96)$ \\
\hline & 1.001 & 1.001 & 0.990 & 0.988 \\
\hline \multirow[t]{3}{*}{ Date squared } & & & $4.173 \mathrm{E}-7 * *$ & $* * \quad 5.004 \mathrm{E}-7 * * *$ \\
\hline & - & - & $(15.82)$ & $(18.45)$ \\
\hline & & & 1.000 & 1.000 \\
\hline \multirow[t]{3}{*}{ Duration } & $-0.00031^{* * *}$ & $-0.00034 * * *$ & $-0.00042 * * *$ & $-0.00045^{* * *}$ \\
\hline & $(-10.69)$ & $(-11.72)$ & $(-13.55)$ & $(-14.52)$ \\
\hline & 1.000 & 1.000 & 1.000 & 1.000 \\
\hline \multirow[t]{3}{*}{ Ex-Yugoslavia } & $0.5845^{* * *} *$ & $0.6156^{* * *}$ & $-347.7 * * *$ & $-385.4 * * *$ \\
\hline & $(22.92)$ & $(23.68)$ & $(-39.59)$ & $(-43.34)$ \\
\hline & 1.795 & 1.851 & 0.000 & 0.000 \\
\hline \multirow[t]{3}{*}{ Date $\times$ Yug } & & & $0.0601 * * *$ & $0.0619 * * *$ \\
\hline & - & - & $(42.32)$ & $(43.29)$ \\
\hline & & & 1.062 & 1.064 \\
\hline \multirow[t]{3}{*}{ Date Squared $\times$ Yug } & & & $-2.4 \mathrm{E}-6 * * *$ & $-2.48 \mathrm{E}-6^{* * *}$ \\
\hline & - & - & $(-42.16)$ & $(-42.99)$ \\
\hline & & & 1.000 & 1.000 \\
\hline \multirow[t]{3}{*}{ Turkey } & $1.0712^{* * * *}$ & $1.0927 * * *$ & $-98.6736^{* * *}$ & $-110.3^{* * *}$ \\
\hline & $(35.59)$ & $(35.94)$ & $(-16.48)$ & $(-18.07)$ \\
\hline & 2.915 & 2.982 & 0.000 & 0.000 \\
\hline
\end{tabular}




\begin{tabular}{|c|c|c|c|c|}
\hline & Model 1 & Model 2 & Model 3 & Model 4 \\
\hline \multirow[t]{3}{*}{ Date $\times$ Tur } & & & $0.0156^{* * *}$ & $0.0176^{* * *}$ \\
\hline & - & - & $(15.68)$ & $(17.25)$ \\
\hline & & & 1.016 & 1.018 \\
\hline \multirow[t]{3}{*}{ Date Squared $\times$ Tur } & & & $-6.08 \mathrm{E}-7 * * *$ & $-6.87 \mathrm{E}-7 * * *$ \\
\hline & - & - & $(-14.75)$ & $(-16.34)$ \\
\hline & & & 1.000 & 1.000 \\
\hline \multirow[t]{3}{*}{ Sri Lanka } & $-2.0798^{* * *}$ & $-2.0390 * * *$ & -21.7067 & $-32.1446^{*}$ \\
\hline & $(-27.19)$ & $(-26.28)$ & $(-1.41)$ & $(-2.07)$ \\
\hline & 0.125 & 0.130 & 0.000 & 0.000 \\
\hline \multirow[t]{3}{*}{ Date $\times$ Sri } & & & 0.00391 & $0.00562 *$ \\
\hline & - & - & $(1.52)$ & $(2.16)$ \\
\hline & & & 1.004 & 1.006 \\
\hline \multirow[t]{3}{*}{ Date Squared $\times$ Sri } & & & $-1.86 \mathrm{E}-7$ & $-2.56 \mathrm{E}-7^{*}$ \\
\hline & - & - & $(-1.73)$ & $(-2.36)$ \\
\hline & & & 1.000 & 1.000 \\
\hline \multirow[t]{3}{*}{ Lebanon } & $-3.1027 * * *$ & $-3.0710 * * *$ & $-3.2762 * * *$ & $-3.2339 * * *$ \\
\hline & $(-12.72)$ & $(-12.59)$ & $(-13.41)$ & $(-13.23)$ \\
\hline & 0.045 & 0.046 & 0.038 & 0.039 \\
\hline \multirow[t]{3}{*}{ Pakistan } & $-0.4451 * * *$ & $-0.4774 * * *$ & $-0.3949 * * *$ & $-0.4404 * * *$ \\
\hline & $(-5.01)$ & $(-5.25)$ & $(-4.41)$ & $(-4.80)$ \\
\hline & 0.641 & 0.620 & 0.674 & 0.644 \\
\hline \multirow[t]{3}{*}{ Somalia } & $-2.1604 * * *$ & $-2.1274 * * *$ & $-2.1933 * * *$ & $-2.1533 * * *$ \\
\hline & $(-17.99)$ & $(-17.60)$ & $(-17.95)$ & $(-17.46)$ \\
\hline & 0.115 & 0.119 & 0.112 & 0.116 \\
\hline \multirow[t]{3}{*}{ Romania } & $-1.0965^{* * *}$ & $-1.0657 * * *$ & $-1.4264 * * *$ & $-1.3760^{* * * *}$ \\
\hline & $(-9.80)$ & $(-9.29)$ & $(-12.58)$ & $(11.83)$ \\
\hline & 0.334 & 0.344 & 0.240 & 0.253 \\
\hline \multicolumn{5}{|l|}{ Diagnostics } \\
\hline Chi-square & $\begin{array}{c}13,875.354 \\
(38 d f)\end{array}$ & $\begin{array}{c}12,429.045 \\
(18 d f)\end{array}$ & $\begin{array}{c}20,967.074 \\
(49 d f)\end{array}$ & $\begin{array}{c}20,273.707 \\
\quad(31 d f)\end{array}$ \\
\hline Gamma & 0.583 & 0.579 & 0.684 & 0.682 \\
\hline Concordant pairs (\%) & 78.6 & 78.4 & 83.8 & 83.6 \\
\hline$N$ & 185,790 & 181,100 & 185,790 & 181,100 \\
\hline
\end{tabular}

NOTE: Entries are unstandardized parameter estimates, $t$-statistics in parentheses, and odds ratios. If the odds ratio is smaller than 1 , an increase in the independent variable decreases the probability of a positive decision, everything else being equal. In the event that it is larger than 1, the probability of the event increases. A value of 1 leaves the odds unchanged. The outcome variable takes the value 1 if an asylum application is accepted ( 0 otherwise). We indicate the cantons with their official abbreviations: $\mathrm{AG}=\mathrm{Aargau} ; \mathrm{AI}=$ Appenzell Innerrhoden; AR = Appenzell Ausserrhoden; BE = Bern; BL = Basel Landschaft; BS = Basel Stadt; FR = Fribourg; GE = Genève; GL = Glarus; GR = Graubünden; JU = Jura; LU = Luzern; NE = Neuchâtel; NW = Nidwalden; OW = Obwalden; $\mathrm{SG}=$ St. Gallen; $\mathrm{SH}=$ Schaffhausen; $\mathrm{SO}=$ Solothurn; $\mathrm{SZ}=$ Schwyz; TG = Thurgau; TI = Ticino; UR = Uri; VD = Vaud; VS = Valais; ZG = Zug; ZH = Zürich.

$* p<.05 . * * p<.01 . * * * p<.0001$. 


\section{REFERENCES}

Achermann, Alberto. 1997. Die Grundlagen der europäischen Asylharmonisierung. Paper presented at a Conference on European Law, University of Bern, 17 January.

Achermann, Alberto, and Christian Hausamman. 1991. Handbuch des Asylrechts. Bern, Switzerland: Haupt.

Becker, Gary S. 1965. The economics of discrimination. Chicago: University of Chicago Press.

Bendor, Johnathan, and Dilip Mookherjee. 1987. Institutional structure and the logic of an ongoing collective action. American Political Science Review 81: 129-54.

Boeles, Pieter, and Ashley Terlouw. 1997. Minimum guarantees for asylum procedures. International Journal of Refugee Law 9: 472-91.

Bundesrat. 1977. Botschaft zum Asylgesetz und zu einem Bundesbeschluss betreffend den Rückzug des Vorbehaltes zu Artikel 24 des Übereinkommens über die Rechtsstellung der Flüchtlinge. Bundesblatt III.

Calvert, Randall L., Mathew D. McCubbins, and Barry R. Weingast. 1989. A theory of political control and agency discretion. American Journal of Political Science 33: 588-611.

Epstein, David, and Sharyn OHalloran. 1994. Administrative procedures, information, and agency discretion. American Journal of Political Science 38: 697-722.

. Forthcoming. Delegating powers: A transaction costs approach to policy making under separate powers. Unpublished book manuscript, Columbia University Press.

Frey, Bruno S., and Iris Bohnet. 1993. Democracy by competition: Referanda and federalism in Switzerland. Publius, 23(2): 71-81.

Frey, Martin. 1988. Swiss asylum law: Recent changes. Georgetown Immigration Law Journal 2: 439-46.

Hailbronner, Kay. 1998. European immigration and asylum law under the Amsterdam Treaty. Common Market Law Review 35: 1047-67.

Hailbronner, Kay, and Claus Thiery. 1997. Schengen II and Dublin: Responsibility for asylum applications in Europe. Common Market Law Review 34: 957-89.

Holzer, Thomas, and Gerald Schneider. 1999. Convergence towards exclusion: The Schengen agreement and the asylum regime in the OECD area. In International migration and liberal democracies, edited by Ansel Schulte and Dietrich Thränhardt, 237-68. Münster, West Germany: LIT.

Holzer, Thomas, and Gerald Schneider. Forthcoming. Asylpolitik auf Abwegen. Unpublished book manuscript.

Holzer, Thomas, Gerald Schneider, and Thomas Widmer. Forthcoming. Assaulting the asylum regime: The impact of legislative deterrence measures on Swiss refugee policy, 1986-1995. International Migration Review.

Höpflinger, François, and Kurt Wyss. 1993. Vollzugsprobleme der öffentlichen Sozialhilfe: Grenzen des Föderalismus im Bereich der wirtschaftlichen Existenzsicherung. Schweizerisches Jahrbuch für Politische Wissenschaft 33: 113-42.

Howse, Robert. 1995. Federalism, democracy, and regulatory reform: A skeptical view of the case for decentralization. In Rethinking federalism: Citizens, markets and governments in a changing world, edited by Karen Knop, Sylvia Ostry, Simeon Richard, and Katherine Swinton, 273-93. Vancouver, Canada: UBC Press.

Joppke, Christian. 1997. Asylum and state sovereignty: A comparison of the United States, Germany, and Britain. Comparative Political Studies 30: 259-98.

. 1998. Why liberal states accept unwanted immigration. World Politics 50: 266-93.

Kälin, Walter. 1990. Grundriss des Asylverfahrens. Basel, Switzerland: Helbing+Lichtenhahn.

Keely, Charles B., and Sharon Stanton Russell. 1994. Responses of industrial countries to asylum-seekers. Journal of International Affairs 47: 399-417.

Kollman, Ken, John H. Miller, and Scott E. Page. 1997. Political institutions and sorting in a Tiebut model. American Economic Review 87: 977-92.

Koritansky, John C. 1987. Decentralization and civic virtue in Tocquevilles new science of politics. In Federalism as grand design: Political philosophers and the federal principle, edited by Daniel J. Elazar, 179-98. Boston: University Press of America. 
McDowell, Christopher. 1996. A Tamil asylum diaspora: Sri Lankan migration, settlement and politics in Switzerland. Providence/Oxford: Berghahn.

McKinnon, Ronald, and Thomas Nechyba. 1997. Competition in federal systems: The role of political and financial constraints. In The new federalism: Can the states be trusted? edited by John Ferejohn and Barry R. Weingast, 3-64. Standford: Hoover Institution.

Miles, Robert, and Dietrich Thränhardt. 1995. European integration, migration and processes of inclusion and exclusion. In Migration and european integration, edited by R. Miles and D. Thränhardt, 1-12. London: Pinter.

Niskanen, William. 1971. Bureaucracy and representative government. Chicago: Aldine.

Nüssli, Kurt. 1985. Föderalismus in der Schweiz: Konzepte, Indikatoren, Daten. Grüsch: Rüegger.

Oates, Wallace E. 1972. Fiscal federalism. Orlando, FL: Harcourt, Brace, Jovanovich.

Parini, Lorena. 1996. La théorie des systèmes auto-organisés et l'étude des phénomènes socio-politiques. Etude de cas: la politique d'asile en Suisse. Ph.D. dissertation, University of Geneva.

Persson, Torsten, and Guido Tabellini. 1996. Federal fiscal constitution: Risk sharing and moral hazard. Econometrica 64: 623-46.

Peterson, Paul E. 1995. The price of federalism. New York: Twentieth Century Fund.

Pressman, Jeffrey L., and Aaron Wildavsky. 1973. Implementation: How great expectations in Washington are dashed in Oakland or, why it's amazing that federal programs work at all. Berkeley: University of California Press.

Ramos, Henry A. 1990. Recent developments affecting the international legal rights of asylum-seekers in Switzerland: An overview and critique. Connecticut Journal of International Law 6: 53-102.

Riker, William H. 1964. Federalism: Origin, operation, significance. Boston: Little, Brown.

Schneider, Friedrich. 1998. Subsidiarity, federalism and direct democracy as basic elements of a federal European constitution: First ideas using constitutional economics. Paper presented at the NEMEU research seminar, EU enlargement towards Eastern Europe, Amsterdam (Netherlands), February 12-15.

Shapiro, David L. 1995. Federalism: A dialogue. Evanston, IL: Northwestern University Press.

Spörndli, Markus, Thomas Holzer, and Gerald Schneider. 1998. Diener Dreier Herren: Kantonalbehörden und die Vollzugsvielfalt der arbeitsmarktlichen Bestimmungen im schweizerischen Asylrecht. Swiss Political Science Review 4 (3): 53-77.

Tiebout, Charles M. 1956. A pure theory of local expenditures. Journal of Political Economy 64: 416-24.

Vanheule, Dirk. 1997. A comparison of the judicial interpretations of the notion of a refugee. In Europe and refugees: A challenge? edited by Jean-Yves Carlier and Dirk Vanheule, 91-105. Dordrecht, the Netherlands: Kluwer.

Widmer, Thomas, and Christof Buri. 1992. Brüssel oder Bern: Schlägt das Herz der Romands eher für Europas? Ein Vergleich der Einstellungen von Deutsch-und Westschweizerinnen zur Europa-Frage. Schweizerisches Jahrbuch für Politische Wissenschaft 32: 363-87. 